\title{
Development of Power Signal Distributor for Electronic Power Meters
}

\author{
In-Yeup Kong, Ho-Jin Kim
}

School of Electronic Engineering, Kumoh National Institute of Technology, Republic of Korea

\begin{abstract}
The Power Signal Distribution Device is a device that distributes the watt pulse (WP) and the End of the interval (EOI) in real time by receiving the power signal from the electronic power meter installed in a building or factory. It is possible to prevent electrical damage of the electronic power meter due to the abnormally applied back electromotive force. And it is possible to construct a redundant system of demand controller and power surveillance system by calculating and analyzing power consumption through power signal provided by the electronic power meter. It is also applicable to demand response monitoring device.
\end{abstract}

Keywords - Demand Controller, Demand Response, Electric Power Management, Maximum Peak Power.

\section{INTRODUCTION}

Signal distributor for digital power meter distributes the watt pulse (WP) and the End of the interval (EOI) signals to multiple equipment such as peak power management devices and demand controllers. It is possible to prevent the electrical damage of the dig ital power meter due to the counter electromotive force applied abnormally in the power management apparatus and to analyze the power use amount through the data provided in the digital power meter and to establish the redundancy of the maximum power management and power management system. In addition, it is a device capable of providing a power signal with a demand response management terminal.

The peak power is the maximum electric power load in a certain period as the base charge of the electricity charge, and is expressed in $\mathrm{kW}$. Although there is a difference between the method of predicting the power and the method of controlling the load power according to the technical specifications proposed by KEPCO, the functions of the device for managing the maximu $\mathrm{m}$ power are the same.

As shown in Fig. 1, when the maximum power management device receives a signal from the meter and calculates the amount of load power in real time. If it is predicted that the used power amount exceeds the target power amount, the connected load device is stepwise blocked, and does not exceed the target amount of power. [1][2]

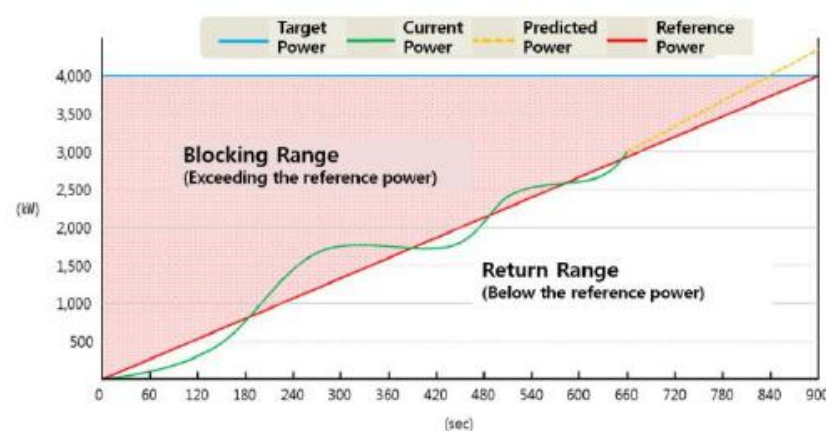

Fig. 1: Management of Peak Power

Demand Response is a sub-concept of demand management as showed in Fig. 2. It refers to activities to maintain balance of supply and demand through adjustment of electricity rate or power reduction by instruction of load reduction in case of supply / demand crisis due to peak of electricity demand. It is a technology that induces the change of electricity usage patterns of electric consumers according to the electricity supply situation such as the peak period through the demand management plan and incentive system.[3]

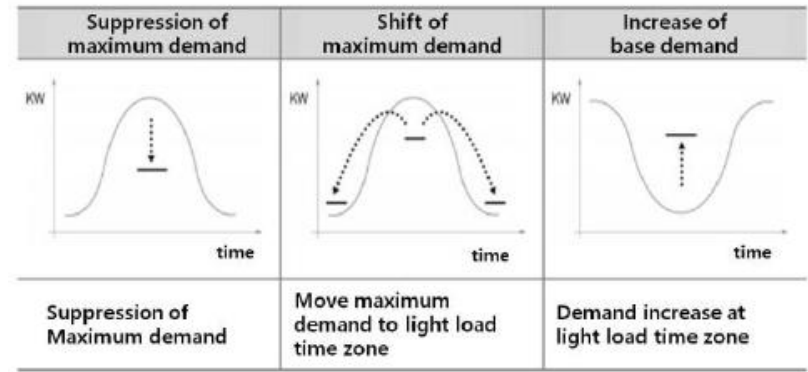

Fig. 2: Demand Response

\section{SIGNAL DISTRIB UTOR}

1. Overall System Architecture

Power management system using signal distributor is showed in Fig.3. 


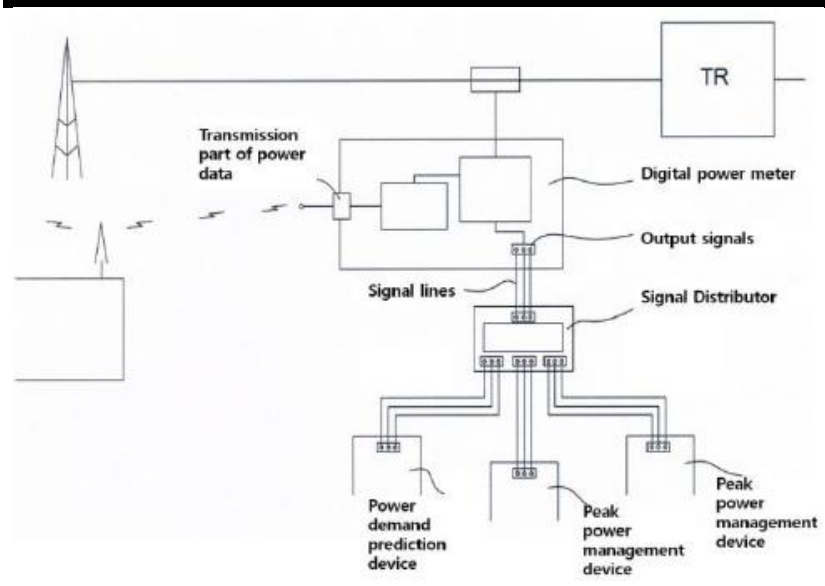

Fig. 3: System Architecture

Signal distributor receives integrating power signal (WP) signal and EOI signals at intervals of 15 minutes from KEPCO digital meter. And then it disperses the signals to various power management devices.

Because this distributor separates signals from meters, we can protect external signal points of meters from the falling of a thunderbolt. Moreover, it helps to make duplex configuration of peak power management system, and to provide synchronization information between power data detected from SCADA and data from KEPCO.

\section{Internal Configuration}

Fig. 4 and Fig. 5 show internal module and flowchart of signal distributor for each.

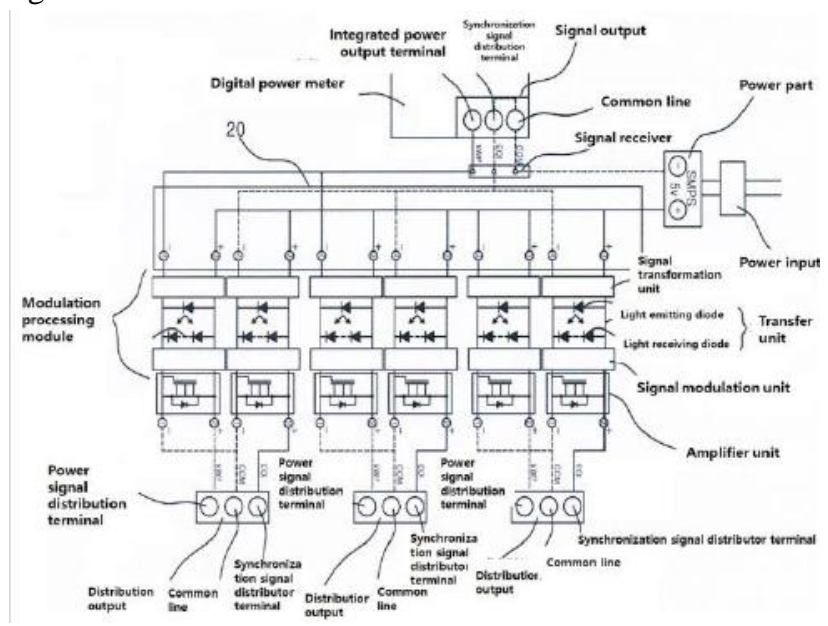

Fig. 4: Internal Configuration of Signal Distributor

Signal distributor consists of signal receiving unit, signal distribution unit, modulation processing unit, and power unit. The signal receiving unit receives kWP signal, and EOI signal from digital power meter. The signal distribution unit distributes the power management signals received at the signal receiving unit through a plurality of distribution circuit paths. The modulation processing unit modulates each of the power management signals distributed in the signal distribution unit and generates a distributed power management signal of the signal strength corresponding to the power management signal output from the digital power meter, respectively. The power unit provides power for outputting distribution power management signals generated by modulation processing unit through dis tribution terminals.

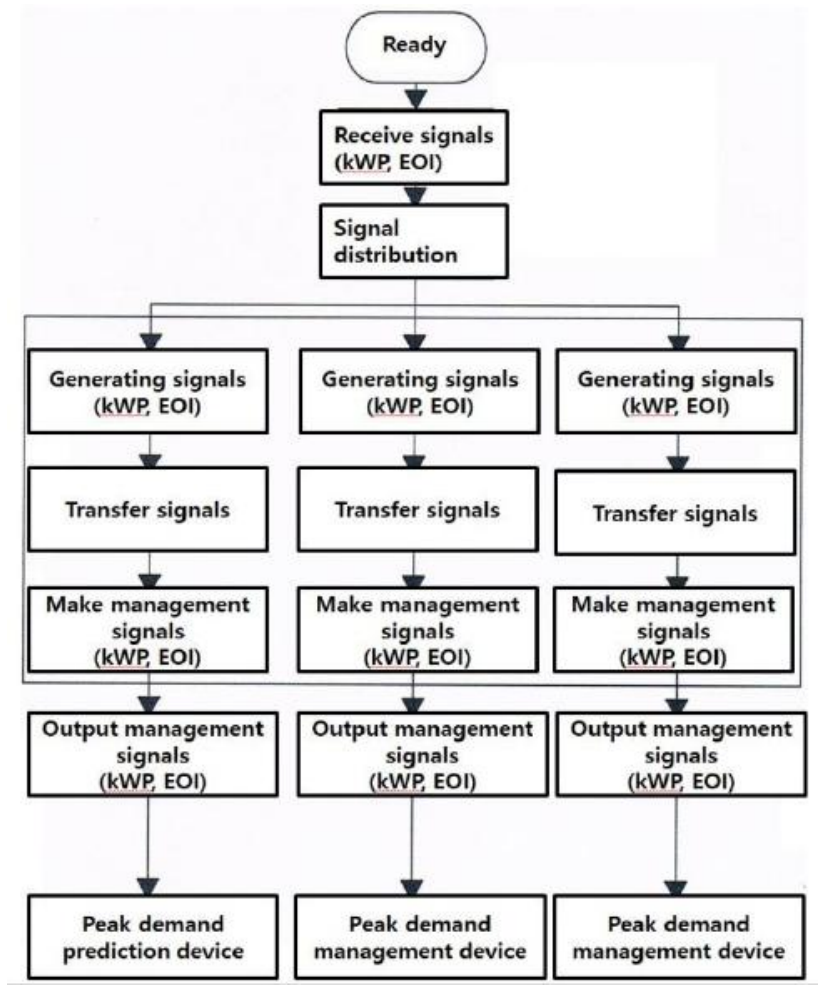

Fig. 5: Flowchart of Signal Distributor

\section{Specification}

Specification of signal distributor is showed in Fig. 6 and Table 1.

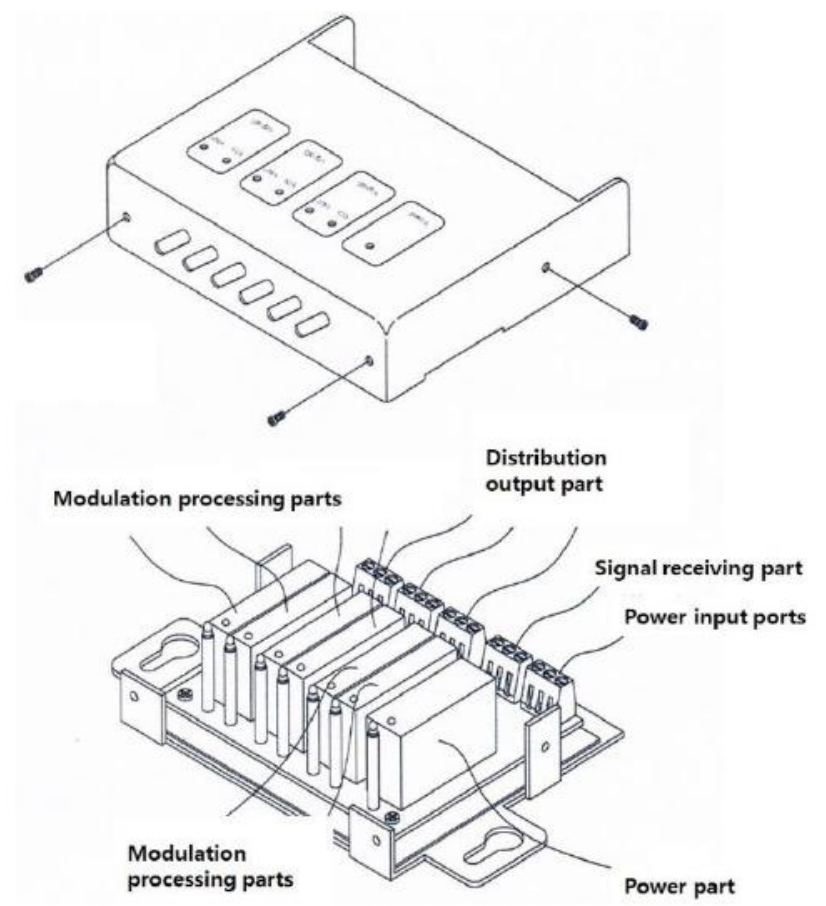

Fig. 6: External view of Signal Distributor 
Table 1: Specification of Signal Distributor

\begin{tabular}{|c|c|}
\hline Features & Specification \\
\hline Operating Temp. & $-20 \sim 45^{\circ} \mathrm{C}$ \\
\hline Storage Temp. & $0 \sim 45^{\circ} \mathrm{C}$ \\
\hline Operating Humidity & $\begin{array}{c}\text { 5 95\% RH, dew should be } \\
\text { formed }\end{array}$ \\
\hline Storage Humidity & $\begin{array}{c}5 \sim 95 \% \mathrm{RH}, \text { No dew should be } \\
\text { formed }\end{array}$ \\
\hline Power Input & AC $100 \sim 240 \mathrm{VAC}$, \\
\hline Power Output & $50 \sim 60 \mathrm{~Hz} / \mathrm{DC}$, More than $1 \mathrm{~A}$ \\
\hline Standby Power & 5VDC, $1 \mathrm{~A}$ max \\
\hline Efficiency & $0.15 \mathrm{~W}$ below \\
\hline
\end{tabular}

\section{Interworking method}

Input/output terminal of signal distributor has 3 parts: power part, input part from KEPCO meters and output part to distribute signals showed in Fig. 7.

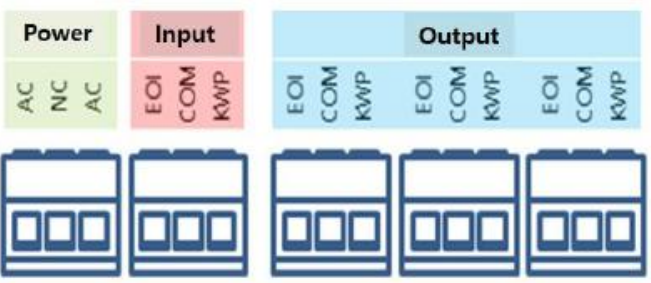

Fig. 7: Input/output Terminals of Signal Distributor

To connect our signal distributor with peak power management device or demand control device, it should be connected as showed in Fig. 6. After signals (EOI, $\mathrm{kWP}, \mathrm{COM}$ ) from power meter are connected to input part of signal distributor, it should be connected to output part(7 9 terminal, 10 12 terminal, or 13 15 terminal) for peak power management device. If an interlocking error occurs, most of all, the terminal connection is often wrong, and then the power calculation in the device received from the output unit is not performed properly.

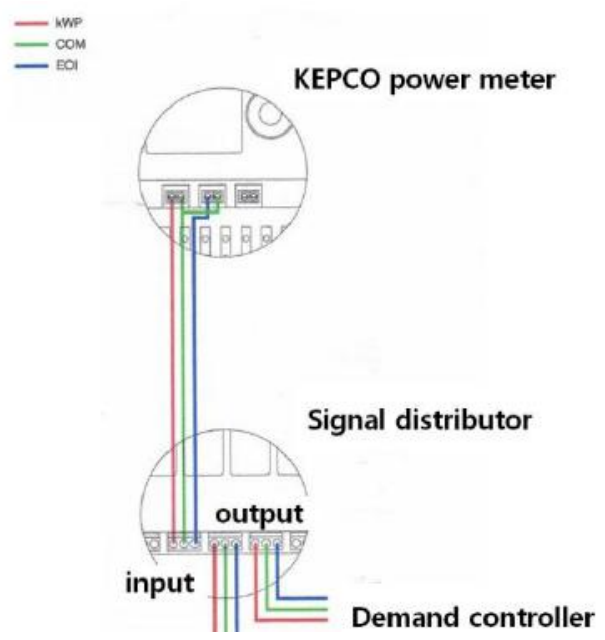

Fig. 6: Connection of Signal Distributor

\section{DURABILITY TESTS}

1. Voltage Dip / Surge Immunity Test

Signal distributor for this test blinks kWP LEDs every 2 seconds and EO LEDs every 10 seconds. We use EMS Tester of EMC partner (Model: IMU4000) as measuring equipment, and $\mathrm{XBC}-\mathrm{DR} 32 \mathrm{H}$ as $\mathrm{KEPCO}$ meter signal generator.

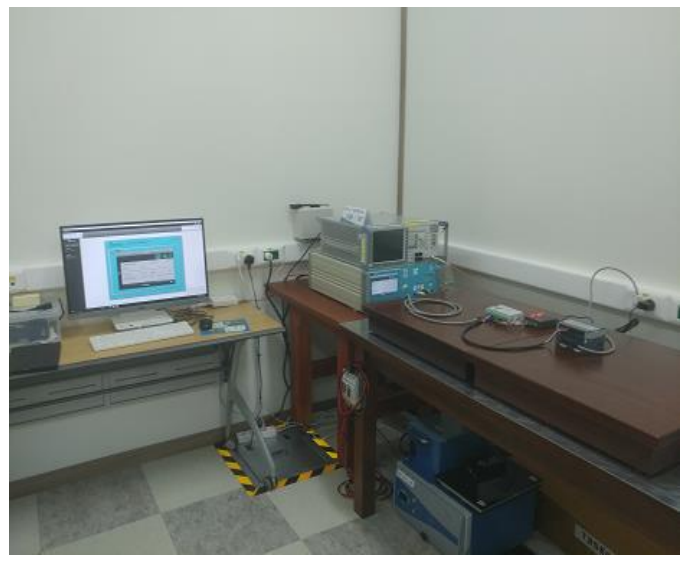

Fig. 9: Voltage Dip/ Surge Immunity Tests

Result of voltage dip immunity test and surge resistance test are as showed in Table 2 and Table 3.

Table 2: Results of Voltage Dip Immunity Test

\begin{tabular}{|c|c|c|c|}
\hline $\begin{array}{c}\text { Input } \\
\text { Voltage/ } \\
\text { Freque } \\
\text { ncy }\end{array}$ & Test & Voltage Dip Level & $\begin{array}{c}\text { Test } \\
\text { Resul } \\
\text { t }\end{array}$ \\
\hline \multirow{4}{*}{$\begin{array}{c}\mathrm{AC} \\
220 \mathrm{~V} / \\
60 \mathrm{~Hz}\end{array}$} & \multirow{3}{*}{$\begin{array}{c}\text { Voltage } \\
\text { Dip }\end{array}$} & $\begin{array}{c}30 \% \text { voltage drop of } \\
\text { supply voltage during } 30 \\
\text { cycles }\end{array}$ & Pass \\
\hline & & $\begin{array}{c}100 \% \text { voltage drop of } \\
\text { supply voltage during } 1 \\
\text { cycles }\end{array}$ & Pass \\
\hline & & $\begin{array}{c}100 \% \text { voltage drop of } \\
\text { supply voltage during } 0.5 \\
\text { cycles }\end{array}$ & Pass \\
\hline & $\begin{array}{c}\text { Voltage } \\
\text { Sag }\end{array}$ & $\begin{array}{l}100 \% \text { voltage drop of } \\
\text { supply voltage during } \\
300 \text { cycles }\end{array}$ & Pass \\
\hline
\end{tabular}

Table 3: Results of Surge Resistance Test

\begin{tabular}{|c|c|c|c|}
\hline $\begin{array}{c}\text { Applied } \\
\text { Terminal }\end{array}$ & $\begin{array}{c}\text { Applie } \\
\text { d Level }\end{array}$ & Number of Tests & $\begin{array}{c}\text { Test } \\
\text { Resul } \\
\mathbf{t}\end{array}$ \\
\hline L-N & $\pm 1 \mathrm{kV}$ & 5 & Pass \\
\hline
\end{tabular}

2. Lightning Impulse Test (Voltage Withstanding) After connecting to digital power meter (EOI output, power output line, common line, and DC line), we apply 
lightning impulse withstanding voltage and check whether it normally operates after lightning impulse test.

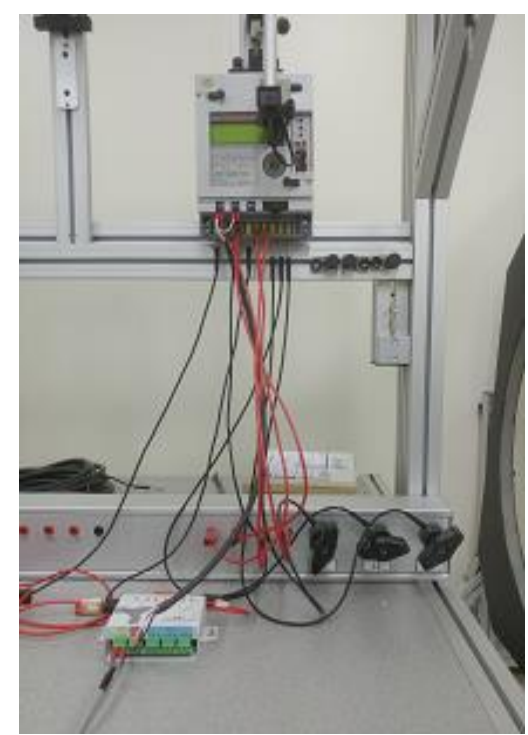

Fig. 10: Lightning Impulse Tests

Table 4: Results of Lightning Impulse Test

\begin{tabular}{|c|c|c|}
\hline Test Basis & $\begin{array}{l}\text { Applied } \\
\text { Position }\end{array}$ & $\begin{array}{c}\text { Test } \\
\text { Result }\end{array}$ \\
\hline \multirow{5}{*}{$\begin{array}{l}\text {-Applied Voltage: } 6,000 \mathrm{~V} \\
\text {-Waveform: }(1.2 / 50) \mu \mathrm{s} \\
\text {-Polarity and Frequency: } 10 \\
\text { times each positive / negative } \\
\text { polarity } \\
\text {-Minimum interval of } \\
\text { application: } 3 \text { seconds } \\
\text {-Connection: connected to EOI } \\
\text { output line, power output line } \\
\text { and common line and signal } \\
\text { line providing equipment of } \\
\text { electronic power meter } \\
\text {-Acceptance Criteria: Check } \\
\text { whether the signal line } \\
\text { providing equipment and the } \\
\text { power meter are in normal } \\
\text { operating condition after the } \\
\text { test of the lightning impulse } \\
\text { withstanding test }\end{array}$} & $\begin{array}{c}\text { Between } \\
\text { EOI input } \\
\text { and ground }\end{array}$ & Pass \\
\hline & $\begin{array}{c}\text { Between } \\
\text { power input } \\
\text { terminal and } \\
\text { ground }\end{array}$ & Pass \\
\hline & $\begin{array}{c}\text { Between } \\
\text { common } \\
\text { line and } \\
\text { ground }\end{array}$ & Pass \\
\hline & $\begin{array}{l}\text { Between } \mathrm{P} \\
\text { line of signal } \\
\text { providing } \\
\text { device and } \\
\text { ground }\end{array}$ & Pass \\
\hline & $\begin{array}{l}\text { Between } L \\
\text { line of signal } \\
\text { providing } \\
\text { device and } \\
\text { ground }\end{array}$ & Pass \\
\hline $\mathrm{n}: 24.7^{\circ}$ & $\%$ R.H., & \\
\hline
\end{tabular}

\section{CONCLUSION}

In this paper, we designed and implemented the signal distributor for electronic power meters. And we verify our module as results of voltage dip immunity test, surge resistance test and lightning impulse test. Our result helps to improve scalability and stability. For the further works, we try to extend it for real-time peak power monitoring and analysis.

\section{ACKNOWLEDGEMENTS}

This research was supported by National Research Foundation of Korea (Project No. 2017-218-007)

\section{REFERENCES}

[1] Byeong-Yong M, Ho-J in K, Young-Hoon K (2013). "Development of Electric Power Management System for Electric Furnace,". Proceedings of the Korean Institute of Information and Communication Sciences Conference, 904-907.

[2] Korea Power Exchange, http://www.kpx.or.kr/ .

[3] DSM (Demand Side Management) site of KEPCO (Korea Electric Power Corporation), http://home.kepco.co.kr/kepco/CY/K/F/CYKFPP001/ main.do?menuCd=FN020706 .

[4] Ho-Jin K, In-Yeup Kong (2019). "Energy Management System Supporting Variable Demand for Digital Power Meters,", International Journal of Science and Engineering Investigations, 8(85), 8690. 